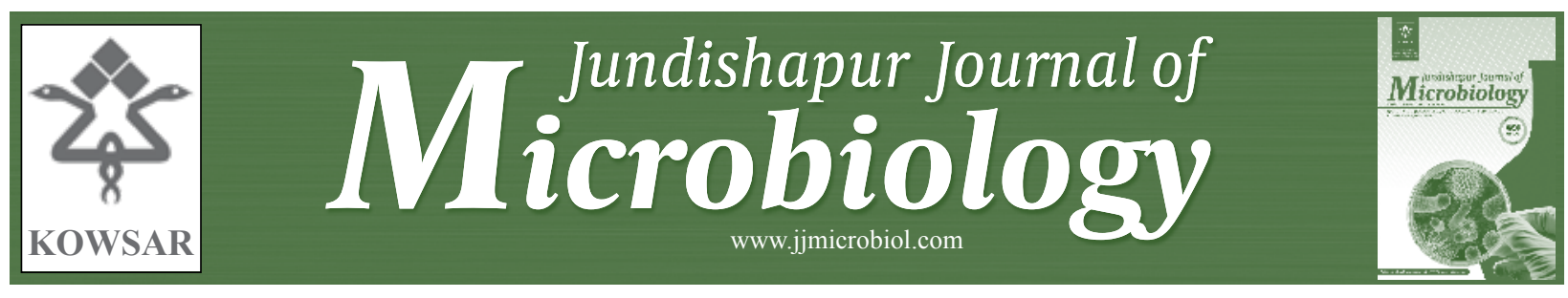

\title{
Seroepidemiology of Human Immunodeficiency Virus in Illicit Substance Users in Ahvaz, Iran: 2005-2006
}

\author{
Seyed Mohammad Alavi ${ }^{1,2^{*}}$, Mohammad Nadimi ${ }^{2}$, Shahram Shokri ${ }^{2}$, Gholamabbas Zamani ${ }^{3}$ \\ ${ }^{1}$ Joundishapur Infectious and Tropical Diseases Research Center, Ahvaz, IR Iran \\ 2 Infectious Disease Ward, Razi Hospital , Joundishapur University of Medical Sciences, Ahvaz, IR Iran \\ ${ }^{3}$ Health Ministry of Iran, IR Iran
}

\begin{tabular}{l}
\hline A R T I C L E I N F O \\
\hline Article type: \\
Original Article \\
\hline Article history: \\
Received: 10 Nov 2011 \\
Revised: 28 Jan 2012 \\
Accepted: 30 Jan 2012
\end{tabular}

Keywords:

HIV

HIV Seroprevalence

\begin{abstract}
A B S T R A C T
Background: A high seroprevalence rate of human immunodeficiency virus (HIV) infection has been reported among Iranian illicit substance users (ISUs).

objectives: The aim of this study was to evaluate the prevalence of HIV and its risk factors in this population.

Patients and Methods: A total of 228 ISUs were included in this cross-sectional study, which was conducted in Ahvaz, southern Iran, from 2005 to 2006 . The study population was randomly selected from available ISUs in prisons and addiction treatment centers. Subjects were tested for the presence of anti-HIV antibodies using the enzyme linked immunosorbent assay (ELISA) method. Drug use behaviors associated with HIV transmission (i.e., high-risk behaviors) and their current sexual risk behaviors were examined.

Results: Sixty two (27.2\%; $95 \%$ CI: 22.5\%-31.8\%) of the 228 men were HIV positive. The prevalence of HIV positivity in injecting, inhalant and oral users was $50.2 \%, 10.4 \%$, and $7.6 \%$, respectively. HIV was positive in heroin, crack and opium users with a rate of $96.2 \%, 83.3$ $\%$, and $1.4 \%$, respectively. Among the HIV infected cases, the vast majority had engaged in high-risk behaviors, including sharing needles ( $72 \%)$, the majority of the injectors had also had unprotected sex with women (67.7\%), or with men (22.6\%).

Conclusions: Illicit substance usage is associated with an increased risk of exposure to HIV and this results in a high prevalence of HIV infection. Heroin injecting, sexually transmitted diseases (STD), having sex with multiple partners, unprotected sex, a long period in prison, early adulthood, and family contact with HIV infected cases, are considered to be the main risk factors for HIV infection.
\end{abstract}

Copyright $\odot 2012$ Kowsar Corp. All rights reserved.

Implication for health policy/practice/research/medical education:

The results of this study are useful for health policy in HIV control.

Please cite this paper as:

Alavi SM, Nadimi M, Shokri S, Zamani G. Seroepidemiology of Human Immunodeficiency Virus in Illicit Substance Users in Ahvaz, Iran: 2005-2006. Jundishapur J Microbiol. 2012;5(3):474-8. DOI: 10.5812/jjm.3446

\section{Background}

HIV has been threatening the lives and health of people all over the world in recent years. Use of intravenous drug is one of the main risk behaviors for the transmission of

\footnotetext{
* Corresponding author: Seyed Mohammad Alavi, Infectious and Tropical Diseases Research Center, Ahvaz, IR Iran. Tel: +98-6113387724, Fax:+989161184916, E-mail: alavi.seyedmohammad@yahoo.com

DOI:10.5812/jjm.3446

Copyright @2012 Kowsar Corp. All rights reserved.
}

$\operatorname{HIV}(1,2)$. As a result, there is a high prevalence (up to 30 $\%)$ of this infection among intravenous drug users (IDUs) $(3,4)$. Similarly, the heterosexual spread of HIV associated with IDUs in the USA and Europe has shown great variations (5). Glesser et al. reported a significant increase of HIV infected homosexuals and female IDUs in Frankfurt am Main, and other big German cities during 1999 - 2000 (6). However, transmission of this disease depends enormously on individual behavior, i.e. personal habits that are subject to changes and variations in social circum- 
stances, beliefs, lifestyles and the availability of information $(7,8)$, hence, patterns of seroprevalence may also change (9). There has been limited data on HIV infections reported from illicit substance users (ISUs) attending drug addiction treatment centers in Ahvaz, Iran. Since the first report of an HIV infection in 1999 among prisoners in Kermanshah, a western province of Iran, a high prevalence of HIV infection has been reported in IDU prisoners by Iranian CDC and several researchers during HIV surveillance in prisons (10).

\section{Objectives}

No studies have been conducted among the ISUs for HIV infection in Ahvaz. Therefore, the present study was conducted to determine the prevalence and risk factors of HIV infection in ISUs among the IDUs attending drug addiction treatment centers in Ahvaz.

\section{Patients and Methods}

A total of 228 ISUs were included in this cross-sectional study, which was conducted in Ahvaz, southern Iran, from 2005 to 2006. This study was part of an approved proposal funded by the Jundishapur Infectious and Tropical Disease Research Center, affiliated to the Jundishapur University of Medical Sciences. The study population was randomly selected from available ISUs in prisons and addiction treatment centers.

After a through physical examination, the subjects completed a questionnaire including; personal information, cigarette smoking, alcohol consumption, imprisonment, duration of time spent in prison, past history of sexually transmitted diseases (STD), sexual behavior, viral hepatitis, HIV infection in his partner or his family and variables related to addiction, such as kind of drug and route of administration.

A blood sample was taken from each participant to be tested for antibodies against HIV. Inclusion criteria were; residency in prison or drug treatment center. Exclusion criteria were; a history of blood or blood products transfusion, operative surgery and receiving anti-retroviral drugs. Antibodies to HIV were detected by an enzyme linked immunosorbent assay (ELISA) and confirmed by a western blot test. Data were analyzed in SPSS 15 (SPSS Inc., Chicago, IL) using; chi-square test, Fisher's exact test and odds ratio with $95 \%$ confidence interval (CI). A p-value less than 0.05 was considered statistically significant.

\section{Results}

All cases studied were male and had a mean \pm SD age of $34.1 \pm 6.1$ (range: 18 - 54) years. Of the 228 cases, 62 (27.2\%; 95 \% CI: $22.5 \%$ - $31.8 \%$ ) were HIV positive. The prevalence of HIV positivity in injecting, inhalant and oral drug abusers was; $50.2 \%, 10.4 \%$, and $7.6 \%$, respectively. There was a significant difference in the positive rates between injecting and non-injecting users $(P<0.0001)$. HIV was positive in heroin, crack and opiate users at a rate of; 96.2 $\%, 83.3 \%$, and $1.4 \%$, respectively. Other results regarding their personal characteristics; coinfection with hepatitis viral infections, HIV infection in partner/family member, route of addiction and type of substance which is used, are shown in Tables 1, 2 and 3. As shown in Table 1, there was no significant difference in age except in the under 25 year group, or level of education, however, there was a significant difference in place of residence between HIV positive and negative cases $(P<0.0001)$. Those with a history of HIV infection in family members or sexual partners had a higher prevalence rate of HIV positivity than the others (Table 2).

Positive history of HIV infection in the sexual partner or a family member was $2.2 \%$, and $1.7 \%$, respectively. The mean \pm SD number of cigarettes smoked per day in HIVpositive and negative subjects were $6.2 \pm 2.6$, and $5.4 \pm$ 3.1, respectively. The mean \pm SD amount of alcohol drunk per day in the two groups was $57.3 \pm 29.7$, and $63.1 \pm 31.3$ $\mathrm{ml}$, respectively. As shown in Table 3, there was a significant difference in the type of substances abused between HIV positive and negative individuals $(p<0.0001)$. The prevalence of HIV positive in the prison and addiction treatment centers was $15.8 \%$, and $13.3 \%$, respectively, but a history of imprisonment in HIV positive cases was higher than in the HIV negative cases (93.3\% vs. $75.3 \%$ ).

\begin{tabular}{|c|c|c|c|}
\hline & $\begin{array}{l}\text { HIV }{ }^{\text {a Positive }} \\
\text {, No. ( \%) }\end{array}$ & $\begin{array}{l}\text { HIV a Negative } \\
\text {, No. (\%) }\end{array}$ & Pvalue $^{b}$ \\
\hline \multicolumn{4}{|l|}{ Age, y } \\
\hline$<25$ & $21(33.9)$ & $25(15.1)$ & 0.002 \\
\hline $25-50$ & $39(62.9)$ & $110(66.2)$ & 0.37 \\
\hline$>50$ & $2(3.2)$ & $31(18.7)$ & 0.001 \\
\hline \multicolumn{4}{|l|}{ Education level } \\
\hline No or little & $49(79.0)$ & $120(72.2)$ & \\
\hline Educated & $13(21.0)$ & $46(27.8)$ & 0.19 \\
\hline \multicolumn{4}{|l|}{ Resident place } \\
\hline Rural & $6(9.7)$ & $63(37.9)$ & \\
\hline Urban & $56(90.3)$ & $103(62.1)$ & $<0.0001$ \\
\hline $\begin{array}{l}\text { Imprisonment, } \\
\text { Duration of prison }\end{array}$ & $58(93.5)$ & $125(75.3)$ & 0.001 \\
\hline$<2$ years & $4(6.4)$ & $10(6.0)$ & 0.55 \\
\hline 2-5 years & $20(32.2)$ & $52(31.3)$ & 0.50 \\
\hline$>5$ years & $34(54.8)$ & $63(37.9)$ & 0.01 \\
\hline $\operatorname{STD}^{a}$ & $30(48.4)$ & $33(19.9)$ & $<0.0001$ \\
\hline \multicolumn{4}{|l|}{ Sexual behavior } \\
\hline Homosexuality & $12(19.4)$ & $18(10.8)$ & 0.07 \\
\hline Heterosexuality & $42(67.7)$ & $40(24.1)$ & $<0.0001$ \\
\hline Condom misuse & $49(79.1)$ & $103(62.1)$ & 0.01 \\
\hline Total & $62(100)$ & $166(100)$ & \\
\hline
\end{tabular}

a Abbreviations: HIV, Human immunodeficiency virus; STD, Sexually transmitted diseases

${ }^{\mathrm{b}} P$ value $<0.05$ is considered significant 


\begin{tabular}{|c|c|c|c|}
\hline & HIV $^{\text {a }}$ Positive, No. ( \%) & HIV $^{\text {a }}$ Negative, No. (\%) & Pvalue $^{\mathrm{b}}$ \\
\hline Positive history of HIV in family member & $4(6.4)$ & $1(0.6)$ & 0.02 \\
\hline Positive history of HIV in partner & $4(6.4)$ & $1(0.6)$ & 0.02 \\
\hline Viral infection: HBsAg positive & $11(17.7)$ & $5(3.0)$ & 0.0003 \\
\hline Anti $\mathrm{HCV}^{\mathrm{a}}$ positive & $35(56.4)$ & $14(8.4)$ & $<0.0001$ \\
\hline Total & $62(100)$ & $166(100)$ & \\
\hline
\end{tabular}

a Abbreviations: HIV, Human immunodeficiency virus; HCV, Hepatitis C virus

${ }^{\mathrm{b}} P$ value $<0.05$ is considered significant

\begin{tabular}{|c|c|c|c|}
\hline & $\begin{array}{l}\text { HIV a Positive, } \\
\text { No. (\%) }\end{array}$ & $\begin{array}{l}\text { HIV }^{\text {a }} \text { Negative, } \\
\text { No. (\%) }\end{array}$ & Pvalue $^{b}$ \\
\hline Cigarette smoker & $62(100)$ & $138(83.1)$ & 0.0001 \\
\hline Alcoholic & $21(33.9)$ & $33(19.9)$ & 0.02 \\
\hline \multicolumn{4}{|l|}{$\begin{array}{l}\text { Route of drug ad- } \\
\text { ministration }\end{array}$} \\
\hline $\mathrm{IV}^{\mathrm{a}}$ & $52(83.8)$ & $57(34.3)$ & $<0.0001$ \\
\hline Inhalation & $5(8.1)$ & $43(25.9)$ & 0.001 \\
\hline Oral & $5(8.1)$ & $61(36.7)$ & $<0.0001$ \\
\hline \multicolumn{4}{|l|}{ Kind of drugs } \\
\hline Heroin & $51(82.2)$ & $2(1.2)$ & $<0.0001$ \\
\hline Crack & $5(8.1)$ & $1(0.6)$ & 0.006 \\
\hline Opiate & $1(1.6)$ & $68(40.9)$ & $<0.0001$ \\
\hline Total & $35(100)$ & $193(100)$ & \\
\hline
\end{tabular}

a Abbreviations: HIV, Human immunodeficiency virus; IV, Intravenous

${ }^{\mathrm{b}} P$ value $<0.05$ is considered significant

Coinfection with hepatitis C virus (HCV) and hepatitis B virus (HBV) was observed in HIV positive cases at the rate of $56.4 \%$ and $17.7 \%$, respectively $(P<0.05)$. Risk factors of HIV infection are shown in Table 4. The most important

risk factors based on odds ratio (OR, $95 \% \mathrm{CI}$ ) are: heroin injection, STD, high risk sexual behavior, imprisonment, HIV infection in family or partner and early adulthood.

\section{Discussion}

The present study revealed that the prevalence of HIV infection was particularly high in the ISUs of Ahvaz, with a rate of $27.2 \%$ for the total ISU population and $50.2 \%$ for IDUs. This finding is higher than the prevalence of HIV infection in seroprevalence studies on HIV among ISUs in many other parts of the world (11-18). Kang et al. in their study on prisoners in New York showed a prevalence rate of $5 \%$, and in Puerto Rico there was a $53 \%$ prevalence rate of anti HIV-antibodies in IDUs (14). Tang et al. also reported a high prevalence of HIV-antibodies among IDUs (17). De la Fuente et al. in a seroepidemiological study on HIV in different population groups, found that the prevalence of HIV-infection in IDUs was $39.6 \%$ - $47.1 \%$ which was higher than in the total population of ISUs (8.7\%) (11). Other reports from Malaysia, Italy and Pakistan suggest a high prevalence of HIV infection (ranging between 5

\begin{tabular}{|c|c|c|c|c|}
\hline & HIV Positive (No:62) & HIV Negative (No:166) & Pvalue & Odds Ratio:95\%CI \\
\hline Age, y & & & & 2.89:1.47-5.68 \\
\hline$<25$ & $21(33.9)$ & $25(15.1)$ & 0.002 & \\
\hline$>25$ & $41(66.1)$ & $141(84.9)$ & & \\
\hline Residency & & & & 5.71:2.32-14.02 \\
\hline Urban & $56(90.3)$ & $103(62.1)$ & $<0.0001$ & \\
\hline Rural & $6(9.7)$ & 63(37.9) & 0.001 & \\
\hline Imprisonment & $58(93.5)$ & $125(75.3)$ & & $4.76: 1.63-13.91$ \\
\hline Prison, y & & & & $3.42: 1.88-6.22$ \\
\hline$>5$ & $34(54.8)$ & $63(37.9)$ & 0.0001 & \\
\hline$<5$ & $24(32.2)$ & $152(37.3)$ & $<0.0001$ & \\
\hline STD & $30(48.4)$ & $33(19.9)$ & & 3.78:2.02-7.07 \\
\hline \multicolumn{5}{|l|}{ Sex behavior } \\
\hline sex with multiple partner & $42(67.7)$ & $40(24.1)$ & $<0.0001$ & $6.62: 3.49-12.55$ \\
\hline Condom misuse & $49(79.1)$ & $103(62.1)$ & 0.01 & 2.31:1.16-4.58 \\
\hline Past history of HIV in family/partner & $4(6.4)$ & $1(0.6)$ & 0.02 & $11.38: 1.25-103.9$ \\
\hline Admin Route & & & & 9.94:4.7-21.03 \\
\hline Injection & $52(83.8)$ & $57(34.3)$ & $<0.0001$ & \\
\hline Non injection & $10(16.2)$ & $109(65.7)$ & & \\
\hline Kind of subst & & & & 380.18:81.50-1771-77 \\
\hline Heroin & $51(82.2)$ & $2(1.2)$ & $<0.0001$ & \\
\hline Others & $11(17.8)$ & $164(98.8)$ & & \\
\hline
\end{tabular}


to $45 \%)$ in ISUs $(13,15,16)$. Although the seroprevalence of HIV in ISUs is higher than in the general population, the rate varies between different countries and even within countries. This difference may be contributed to by various factors such as; socio-economic status, life style, environmental sanitation, geographical variation, sexual behaviors, route of administration, type of substance and differences in assays for anti-HIV antibodies. In the present study, the prevalence rate of HIV infection in non-injectors ranged between $7.6 \%$ and $10.4 \%$, which is significantly higher than in other parts of the world. It is unknown to us why non-injecting ISUs have such a high rate of HIV antibodies. We believe that the high risk sexual behavior of ISUs in the study region, and possibly other routes of HIV transmission (non-injecting) such as; unprotected sex or tattooing, may be contributing to this condition.

We found no association between the presence of antiHIV antibodies and the age of ISUs except in people below the age of 25 years. Previous published studies suggested that early adulthood was significantly associated with anti-HIV antibodies $(12,13,18)$. The correlation of HIV with age may reflect the fact that HIV infection was acquired in adolescence and the HIV antibody has a lifelong persistence. However, our study population with similar poor sexual health practices, regardless of age, is at a similar risk of infection.

This study showed that there was an association between the presence of an HIV infection and variables such as; place of residence, imprisonment, smoking, alcohol consumption, duration of stay in prison, sexual behaviors, type of drugs, route of administration, and condom misuse. Some of these findings are in agreement and some contradict previous reports (2-7, 9-11, 13, 14, 16, 17). We believe that although some of these variables may be true risk factors of HIV infection (e.g. early adulthood, IDU, STD, having sex with multiple partners, unprotected sex, long time in prison and family contact with a HIV infected case), since our study population was at a similar risk for all of these factors, we could not determine a statistically significant difference between the HIV positive and HIV negative cases.

Our study showed that HIV seropositivity was related to the type of substance abused $(P<0.05)$, it was also related to the route of administration $(P<0.05)$. IDUs had a higher prevalence rate of HIV infection than non-IDUs (47.7 \% vs. $15.2 \%$ ). Different routes of exposure have different risk levels, i.e. viremia levels in the blood differ. Perhaps it is worth noting that these findings are consistent with what has been found previously. In this present study the prevalence rate of HIV infection among non-injectors (7.6 $\%)$ was higher than in the general population (0.02\%)(19), and our findings are virtually consistent with that of Vasmani et al. and de la Fuentle et al. $(11,18)$. This finding may reflect the possibility that injection may not be the only route of transmission of HIV in the study region, and ISUs (mostly prisoners) with high risk sexual behaviors such as; homosexuality, misuse of condom and frequent sexual infections could also be infected by HIV. In this study, coinfection with the hepatitis B virus (HBV) or hepatitis C virus (HCV) was associated with a higher rate of HIV infection. Our previous studies and reports from other parts of the world, suggest a high rate of coinfection of HIV, HCV and HBV (19-21). We believe that the high frequency of high risk practices such as; the sharing of injection equipment, unprotected sex and imprisonment, exposes this population to HBV and HCV as well as HIV.

Positive past medical history in family members or partners of the HIV positive cases was significantly different from the HIV negative cases ( $4.8 \%$ - $6.4 \%, 6.2 \%$ vs. $0.6 \%$ ) and this had a confounding effect on our results. However, in our study, the high prevalence of anti-HIV antibodies observed in that group of patients was shown to be due to the confounding effects of variables related to sexual behavior or imprisonment.

In the present study, oral users (Table 3) were at lower risk of infection with HIV in comparison with injectors and inhalators. The reason for the difference is clear between oral users and injectors (7.5\% v.s $96.3 \%$ ), but not so clear for the difference between inhalers and oral users. We suppose that this is because in the study region, opium is the most frequently used substance via the oral route, the lower rate of awareness induced by opium, may result in a reduced rate of unprotected sex in oral users.

This study suggests that illicit substance usage is associated with an increased risk of exposure to HIV and results in a high prevalence of HIV infection in these people. Oral ISUs are at a lower risk of HIV infection than IDUs or inhalers. IDU, STD, having sex with multiple partners, unprotected sex, long time in prison, early adulthood and family contact with an HIV infected case, may be considered to be the main risk factors for an HIV infection.

\section{Acknowledgements}

The authors wish to thank the research deputy of Jundishapur Faculty of Medicine for approval (MD Dissertation No. P/D/103) and chief and personnel of Jundishapur Infectious and Tropical Research Center (JITRC) for supporting this study. We also acknowledge Mr. Taei (expert of HIV/AIDS unit of KHC) for his valuable cooperation.

\section{Financial disclosure}

None declared.

\section{Funding/Support}

This study funded by faculty of medicine

\section{Ethical approval}

This study approved by ethical committee of Jundishapur Faculty of Medicine No. 103. 


\section{References}

1. Lauer GM, Walker BD. Hepatitis C virus infection. $N$ Engl J Med. 2001;345(1):41-52.

2. Rhodes T, Stimson GV, Crofts N, Ball A, Dehne K, Khodakevich L. Drug injecting, rapid HIV spread, and the 'risk environment': implications for assessment and response. AIDS. 1999;13 Suppl A:S259-69.

3. Drugs EMCf, Addiction D. Annual Report 2003: the state of the drugs problem in the European Union and Norway. Office for Official Publications of the European Communities; 2004.

4. Monga HK, Rodriguez-Barradas MC, Breaux K, Khattak K, Troisi $\mathrm{CL}$, Velez $\mathrm{M}$, et al. Hepatitis $\mathrm{C}$ virus infection-related morbidity and mortality among patients with human immunodeficiency virus infection. Clin Infect Dis. 2001;33(2):240-7.

5. Des Jarlais DC, Friedman SR, Stoneburner RL. HIV infection and intravenous drug use: critical issues in transmission dynamics, infection outcomes, and prevention. Rev Infect Dis. 1988;10(1):151-8.

6. Giesser IL, Doerr HW, Rabenau HF. An epidemiological study of HIV-infections in Frankfurt/Main and other major cities in Germany. Int J Hyg Environ Health. 2001;203(5-6):393-9.

7. Hamers FF, Infuso A, Alix J, Downs AM. Current situation and regional perspective on HIV/AIDS surveillance in europe. J Acquir Immune Defic Syndr. 2003;32 Suppl 1:S39-48.

8. O'Sullivan BG, Levy MH, Dolan KA, Post JJ, Barton SG, Dwyer DE, et al. Hepatitis $C$ transmission and HIV post-exposure prophylaxis after needle- and syringe-sharing in Australian prisons. Med J Aust. 2003;178(11):546-9.

9. Hagan H, Des Jarlais DC. HIV and HCV infection among injecting drug users. Mt Sinai J Med. 2000;67(5-6):423-8.

10. UNAIDS. Report on Global Overview of HIV/AIDS epidemia; 2002.

11. de la Fuente L, Bravo MJ, Lew C, Barrio G, Soriano V, Royuela L. [The prevalence of human immunodeficiency virus infection and the risk behaviors in the heroin addicts of Barcelona, Madrid and Seville: an example of the advantages of centering stud- ies on addicts and not just on intravenous users]. Med Clin (Barc). 1999;113(17):646-51.

12. Del Rio C, J.W. C. Epidemiology and prevention of acquired immune deficiency syndrome and human immunodeficiency virus infection. In Mandell GL, et al., eds. Principles and Practice of Infectious Diseases. 6th ed. Philadelphia PE, Inc, editor.; 2005.

13. Emmanuel F, Akhtar S, Attarad A, Kamran C. HIV risk behavior and practices among heroin addicts in Lahore, Pakistan. Southeast Asian J Trop Med Public Health. 2004;35(4):940-8.

14. Kang SY, Deren S, Andia J, Colon HM, Robles R, Oliver-Velez D. HIV transmission behaviors in jail/prison among puerto rican drug injectors in New York and Puerto Rico. AIDS Behav. 2005;9(3):37786.

15. Razali SM. Drug substitution therapy: a new approach in preventing the spread of HIV/AIDS in Malaysia. Trop Doct. 2008;38(2):10910.

16. Spina M, Mancuso S, Sinicco A, Vaccher E, Traina C, Di Fabrizio $\mathrm{N}$, et al. Human immunodeficiency virus seroprevalence and condom use among female sex workers in Italy. Sex Transm Dis. 1998;25(9):451-4.

17. Tang YL, Zhao D, Zhao C, Cubells JF. Opiate addiction in China: current situation and treatments. Addiction. 2006;101(5):657-65.

18. Vaswani M, Desai NG. HIV infection and high-risk behaviors in opioid dependent patients: the Indian context. Addict Behav. 2004;29(8):1699-705.

19. Alavi SM, Ahmadi F, Ghasemirad MR. Seroepidemiological study of hepatitis E virus in drug addicts in Ahvaz, Southern Iran: 20052006. Hepat Mon. 2008;8(4):263-6.

20. Alavi SM. Relative frequency of infections among hospitalized injecting drug user HIV positive patients in Razi hospital, Ahvaz, SW Iran (2001-2003). Jundishapur J Microbiol. 2008;1(1):6-9.

21. Alavi SM, Etemadi A. HIV/HBV, HIV/HCV and HIV/HTLV-1 co infection among injecting drug user patients hospitalized at the infectious disease ward of a training hospital in Iran. Pakistan JMed Sci. 2007;23(4):510. 